\title{
Short Communication \\ OLIVE OIL PROTECTS AGAINST CHROMOSOMAL ABERRATIONS INDUCED BY DOXORUBICIN IN WISTAR RAT BONE MARROW CELLS
}

\author{
Lusânia Maria Greggi Antunes ${ }^{1,3}$ and Catarina Satie Takahashil,2
}

\begin{abstract}
There is considerable interest in identifying dietary compounds which have the capacity to protect against chromosomal aberrations induced by antitumor agents. Fatty acids and their constituents are able to act as free radical scavengers. Doxorubicin (DXR) is an important chemotherapeutic agent, that also induces chromosome aberrations. Rat bone marrow cells treated simultaneously with olive oil ( $10 \mathrm{ml} / \mathrm{kg}$ body weight) and DXR (90 $\mathrm{mg} / \mathrm{kg}$ body weight) developed significantly fewer chromosomal aberrations and abnormal metaphases than those treated with DXR alone.
\end{abstract}

\section{INTRODUCTION}

Recent attention has focused on a number of nonvitamin antioxidants, such as phenolic compounds, that could contribute to antioxidant defense. These phenolic compounds are found in many plant species and are present at very high concentrations in many components of the Mediterranean diet, including olive oil (Manna et al., 1997). Dietary antioxidants would likely exert their protective action by counteracting the oxidative damaging effects on cellular components (Pompella, 1997). The Mediterranean diet is characterized by a predominance of olive oil among seasoning fats, and it is associated with low rates of colorectal carcinoma (Braga et al., 1998). According to Raj and Katz (1984), fatty acids and their constituents are able to act as free radical scavengers. Olive oil is very high in monounsaturated fats and has antioxidant properties (Hill and Glacosa, 1992; Trichopoulou, 1995).

Doxorubicin (DXR) is an important chemotherapeutic agent that induces cardiotoxicity, as well as chromosome aberrations. It is important to reduce its toxicity

${ }^{l}$ Departamento de Genética, Faculdade de Medicina de Ribeirão Preto, USP, Av. Bandeirantes, 3900, 14049-900 Ribeirão Preto, SP, Brasil. Send correspondence to L.M.G.A.

${ }^{2}$ Departamento de Biologia, Faculdade de Filosofia, Ciências e Letras de Ribeirão Preto, USP, Av. Bandeirantes, 3900, 14040-901 Ribeirão Preto, SP, Brasil.

${ }^{3}$ Departamento Anal. Clín. Toxicol. Bromatol., Faculdade de Ciências Farmacêuticas de Ribeirão Preto, USP, Via do Café s/n, 14040-903 Ribeirão Preto, SP, Brasil. in normal cells, a goal that can be achieved by concurrent administration of free radical scavenging agents, such as antioxidants (Amara-Mokrane et al., 1996; Matsuda et al., 1997; Antunes and Takahashi, 1998). The present study was undertaken to investigate the modulatory effect of the simultaneous treatment with olive oil, a dietary antioxidant, on the clastogenic action of DXR in Wistar rat bone marrow cells.

\section{MATERIAL AND METHODS}

Doxorubicin (Adriblastina ${ }^{\circledR}$ ) was donated by Farmitalia Carlo Erba (Brazil). Olive oil $\left(\right.$ Carbonell $\left.^{\circledR}\right)$ was purchased in the local market.

Experiments were carried out on six-week-old rats (Rattus norvegicus) weighing approximately $100 \mathrm{~g}$. Animals were supplied by the animal facilities of the Faculty of Medicine of Ribeirão Preto, University of São Paulo. Food and water were available ad libitum. Rats were divided into experimental groups of six animals each (three males and three females). The DXR (90 mg/kg body weight) was injected intraperitoneally $(0.5 \mathrm{ml} / 100 \mathrm{~g}$ body weight $)$ simultaneously with a single dose of olive oil $(1 \mathrm{ml} / 100 \mathrm{~g}$ body weight) by gavage. Control groups were similarly treated. All animals were injected intraperitoneally with $2 \mathrm{mM}$ colchicine $90 \mathrm{~min}$ before sacrifice, that occurred $24 \mathrm{~h}$ after treatment. Bone marrow preparations for analysis of chromosome aberrations in metaphase cells were obtained by the technique of Ford and Hamerton (1956). One hundred metaphases per animal were analyzed in order to determine the frequencies of chromosomal aberrations in a blind test. The mitotic index was obtained by counting the number of mitotic cells in 2000 cells analyzed per animal. Statistical analyses were done by the Tukey test $(\alpha=0.05)$.

\section{RESULTS AND DISCUSSION}

As expected, animals treated with DXR had a significantly higher frequency of chromosomal aberrations and abnormal metaphases when compared with olive oil alone (Table I). In groups treated with DXR alone or olive oil plus DXR, the most frequent chromosomal aberrations observed were chromatid breaks, followed by complex exchanges $(\mathrm{P}<0.05)$. Animals treated with DXR alone, or a combination of olive oil plus DXR, had a significantly lower mitotic index compared to olive oil alone (Table I). There were no significant differences between sexes $(\mathrm{P}=0.48)$. 
Table I - Mitotic index (MI), distribution of the different types of chromosomal aberrations (CA), and abnormal metaphases (AM) observed in female $(\mathrm{F})$ and male $(\mathrm{M})$ Wistar rat bone marrow cells treated simultaneously with doxorubicin (DXR, $90 \mathrm{mg} / \mathrm{kg}$ body weight) and olive oil (10 $\mathrm{ml} / \mathrm{kg}$ body weight), and respective controls.

\begin{tabular}{|c|c|c|c|c|c|c|c|c|c|c|}
\hline \multirow[t]{3}{*}{ Treatments } & \multirow[t]{3}{*}{ Sex } & \multirow{3}{*}{$\begin{array}{l}\text { MI } \\
(\%)\end{array}$} & \multicolumn{6}{|c|}{ Chromosomal aberrations } & \multirow{3}{*}{$\begin{array}{c}\text { Total } \\
\text { CA }\end{array}$} & \multirow[t]{3}{*}{ AM } \\
\hline & & & \multirow[t]{2}{*}{ Gaps } & \multicolumn{2}{|c|}{ Breaks } & \multirow[t]{2}{*}{$\mathrm{E}$} & \multirow[t]{2}{*}{$\mathrm{T}$} & \multirow[t]{2}{*}{ Q } & & \\
\hline & & & & $\mathrm{C}$ & IC & & & & & \\
\hline \multirow[t]{7}{*}{ Olive oil } & $\mathrm{F}$ & 3.4 & 0 & 0 & 0 & 0 & 0 & 0 & 0 & 0 \\
\hline & $\mathrm{F}$ & 3.6 & 0 & 5 & 0 & 0 & 0 & 0 & 5 & 5 \\
\hline & $\mathrm{F}$ & 2.2 & 0 & 0 & 0 & 0 & 0 & 0 & 0 & 0 \\
\hline & M & 3.0 & 0 & 1 & 0 & 0 & 0 & 0 & 1 & 1 \\
\hline & M & 2.0 & 0 & 1 & 0 & 0 & 0 & 0 & 1 & 1 \\
\hline & M & 3.1 & 0 & 1 & 1 & 0 & 0 & 0 & 2 & 2 \\
\hline & mean $\pm \mathrm{SE}$ & $2.8 \pm 0.26$ & & & & & & & $1.5 \pm 1.87$ & $1.5 \pm 0.76$ \\
\hline \multirow[t]{7}{*}{ DXR } & $\mathrm{F}$ & 1.6 & 0 & 83 & 0 & 22 & 1 & 3 & 109 & 48 \\
\hline & $\mathrm{F}$ & 0.8 & 0 & 68 & 0 & 6 & 0 & 3 & 77 & 47 \\
\hline & $\mathrm{F}$ & 1.3 & 1 & 24 & 1 & 3 & 1 & 1 & 31 & 25 \\
\hline & M & 0.8 & 2 & 51 & 1 & 7 & 0 & 0 & 61 & 37 \\
\hline & M & 1.5 & 1 & 66 & 1 & 10 & 0 & 0 & 78 & 51 \\
\hline & $\mathrm{M}$ & 1.0 & 0 & 44 & 0 & 10 & 0 & 1 & 55 & 33 \\
\hline & mean $\pm \mathrm{SE}$ & $1.7^{*} \pm 0.14$ & & & & & & & $68.5^{*} \pm 10.71$ & $40.2^{*} \pm 4.15$ \\
\hline \multirow[t]{7}{*}{ Olive oil + DXR } & $\mathrm{F}$ & 0.7 & 3 & 19 & 0 & 4 & 0 & 0 & 26 & 24 \\
\hline & $\mathrm{F}$ & 1.6 & 0 & 30 & 0 & 12 & 0 & 1 & 43 & 35 \\
\hline & $\mathrm{F}$ & 0.6 & 0 & 40 & 1 & 3 & 0 & 0 & 44 & 32 \\
\hline & M & 1.1 & 5 & 35 & 1 & 8 & 0 & 0 & 49 & 37 \\
\hline & M & 1.1 & 3 & 20 & 0 & 5 & 0 & 0 & 28 & 24 \\
\hline & $\mathrm{M}$ & 1.8 & 1 & 16 & 1 & 3 & 0 & 0 & 21 & 19 \\
\hline & mean $\pm \mathrm{SE}$ & $1.1^{*} \pm 0.19$ & & & & & & & $35.2^{* * *} \pm 4.71$ & $28.5^{* *} \pm 2.92$ \\
\hline
\end{tabular}

One hundred cells were analyzed per animal, for a total of 600 cells per treatment. C, Chromatid-type; IC, isochromatid-type; E, complex exchange; T, triradial figure; $\mathrm{Q}$, quadriradial figure; $\mathrm{SE}=$ standard error. *Significantly different from olive oil alone $(\mathrm{P}<0.05)$. ${ }^{* *}$ Significantly different from DXR alone $(\mathrm{P}<0.05)$

Olive oil, administered simultaneously with DXR, resulted in a significant reduction in both the total number of chromosomal aberrations and abnormal metaphases induced by DXR (48.6 and 29.0\%, respectively). Raj and Katz (1984) observed a reduction in 7,12-dimethylbenz $[a]$ anthracene-induced chromosomal breaks in mouse bone marrow cells pretreated with corn oil. Irradiated animals pretreated for six months with olive oil also have significantly fewer chromosomal aberrations than those pretreated with water or vitamin E (El-Nahas et al., 1993). Mimnaugh et al. (1979) observed that olive oil did not interfere in the metabolism of DXR in lung, liver and heart in mouse. One possible explanation for the protection against chromosomal damage is that simultaneous treatment with olive oil would allow interception of free radicals generated by clastogenic agents before they reach DNA and induce alterations.

Olive oil-fed rats are remarkably resistant to oxidative modifications induced by copper (Scaccini et al., 1992). Manna et al. (1997) demonstrated that (3,4dihydroxyphenyl) ethanol, present in olive oil, acts as a biological antioxidant in Caco-2 epithelial intestinal cells and protects against oxidative injury. Experimental animal model studies of high dietary fat and cancer have also indicated that olive oil can help prevent a number of chemically induced tumors (Weijl et al., 1997). It has been pro- posed that squalene, found in olive oil, has a protective effect (Newmark, 1997). A favorable effect of olive oil has also been proposed, on the basis of other animal experiments, to be due to the presence of oleic acid, a monounsaturated fatty acid, and specific micronutrients, such as vitamin E (Braga et al., 1998).

In this investigation, the bone marrow cells from animals treated with olive oil had significantly fewer chromosomal aberrations and abnormal metaphases induced by DXR. Indeed more research is needed to assess the impact of olive oil as an antioxidant agent, since it is suggested as an organic solvent in mutagenesis tests (Logan and Salamone, 1988) and could therefore modify the results obtained with compounds of mutagenic potential.

\section{ACKNOWLEDGMENTS}

The authors thank Dr. Sergio Kronka for statistical help and Miss Sueli A. Neves and Mr. Luiz A. Costa Jr. for technical assistance. Research supported by CAPES, CNPq and FAPESP. Publication supported by FAPESP.

\section{RESUMO}

Existe considerável interesse na identificação de componentes da dieta que têm a capacidade de proteger contra as aberrações cromossômicas induzidas pelos agentes 
antitumorais. Os ácidos graxos e seus constituintes são capazes de atuar como seqüestradores de radicais livres. $\mathrm{Na}$ presente investigação, as células da medula óssea dos animais tratados simultaneamente com o óleo de oliva $(10 \mathrm{ml} / \mathrm{kg}$ de peso corporal) e doxorubicina (DXR; $90 \mathrm{mg} / \mathrm{kg}$ de peso corporal) apresentaram uma significativa redução no total de aberrações cromossômicas e metáfases alteradas induzidas pela DXR.

\section{REFERENCES}

Amara-Mokrane, M.P., Lebucher-Michel, G., Balansard, G., Duménil, G. and Botta, B. (1996). Protective effects of $\alpha$-hederin, chlorophyllin and ascorbic acid towards the induction of micronuclei by doxorubicin in cultured human lymphocytes. Mutagenesis 11: 161-167.

Antunes, L.M.G. and Takahashi, C.S. (1998). Effects of high doses of vitamins $\mathrm{C}$ and $\mathrm{E}$ against doxorubicin-induced chromosomal damage in Wistar rat bone marrow cells. Mutat. Res. 419: 137-143.

Braga, C., La Vecchia, C., Francesci, S., Negri, E., Parpinel, M., Decarli, A., Glacosa, A. and Trichopoulos, D. (1998). Olive oil, other seasoning fats, and the risk of colorectal carcinoma. Cancer 82: 448-453.

El-Nahas, S.M., Mattar, F.E. and Mohamed, A.A. (1993). Radioprotective effect of vitamins C and E. Mutat. Res. 301: 143-147.

Ford, C.E. and Hamerton, J.L. (1956). A colchicine, hypotonic citrate, squash sequence for mammalian chromosomes. Stain Technol. 31: 247-251.

Hill, M. and Glacosa, A. (1992). The Mediterranean diet. Eur. J. Cancer Prev. 1: 339-340.

Logan, D.M. and Salamone, M.F. (1988). Plant oil variables and their pos- sible influence in mutagenicity testing. Mutat. Res. 208: 123-127.

Manna, C., Galletti, P., Cucciolla, V., Moltedo, O., Leone, A. and Zappia, V. (1997). The protective effect of the olive oil polyphenol $(3,4-$ dihydroxyphenyl)-ethanol counteracts reactive oxygen metaboliteinduced cytotoxicity in Caco-2 cells. J. Nutr. 127: 286-292.

Matsuda, A., Kimura, M. and Itokawa, Y. (1997). Influence of selenium deficiency on the acute cardiotoxicity of adriamycin in rats. Biol. Trace Elem. Res. 57: 157-167.

Mimnaugh, E.G., Siddik, Z.H., Drew, R., Sikic, B.I. and Gram, T.E. (1979). The effects of $\alpha$-tocopherol on the toxicity, disposition, and metabolism of adriamycin in mice. Toxicol. Appl. Pharmacol. 49: 119-126.

Newmark, H.L. (1997). Squalene, olive oil, and cancer risk: a review and hypothesis. Cancer Epidemiol. Biomarkers Prev. 6: 1101-1103.

Pompella, A. (1997). Biochemistry and histochemistry of oxidative stress and lipid peroxidation. Int. J. Vit. Nutr. Res. 67: 289-297.

Raj, A.S. and Katz, M. (1984). Corn oil and its minor constituents as inhibitors of DMBA-induced chromosomal breaks in vivo. Mutat. Res. 136: $247-253$

Scaccini, C., Nardini, M., D'Aquino, M., Gentili, V., Di Felice, M. and Tomassi, G. (1992). Effect of dietary oils on lipid peroxidation and on antioxidant parameters of rat plasma and lipoprotein fractions. $J$. Lipid Res. 33: 627-633.

Trichopoulou, A. (1995). Olive oil and breast cancer. Cancer Causes Control 6: 475-476.

Weijl, N.I., Cleton, F.J. and Osanto, S. (1997). Free radicals and antioxidants in chemotherapy-induced toxicity. Cancer Treat. Rev. 23: 209240 .

(Received April 27, 1998) 
